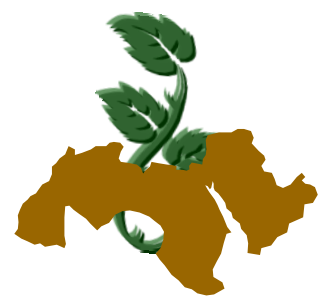

Arab Univ.

\title{
PHYSICOCHEMICAL PROPERTIES AND ITS APPLICATION OF DILL (AN- ETHUM GRAVEOLENS) AND PARSLEY (PETROSELINUM SATIVUM) AND THEIR ESSENTIAL OILS
}

\author{
Tolba1 , K.H.; S.M. Youssef ${ }^{1}$ and E.S. Abd-Elwahab ${ }^{1}$ \\ 1- Food Technology Res. Institute, Agric. Res. Center, Giza, Egypt
}

Keywords: Dill (Anethum graveolens), Parsley (Petroselinum sativum), Chemical composition, Essential oils, Application

\begin{abstract}
The chemical composition for both dill and parsley herbs were studied. The highest content of crude protein, crude fiber, ash content, carotenoids, total chlorophyll and essential oil contents were found in dill herb were $27.25,13.38,16.02 \%$, 174.32 , $530.47 \mathrm{mg} / 100 \mathrm{~g}$ and $0.879 \%$ (on dry weight basis), respectively, compared with that found in parsley. On the other hand, parsley was rich in both of ascorbic acid and $\beta$-carotene which were 682.77 and $34.95 \mathrm{mg} / 100 \mathrm{~g}$ (on dry weight basis), respectively. Minerals content of dill and parsley herbs were analyzed and the results indicated that the dill contained higher amounts of $\mathrm{Na}$, $\mathrm{Ca}, \mathrm{Cu}$ and $\mathrm{Zn}$ than that found in parsley. Some physical properties of dill and parsley essential oils such as (color, specific gravity at $15^{\circ} \mathrm{C}$, refractive index at $20^{\circ} \mathrm{C}$, optical rotation and solubility in diluted ethyl alcohol) and some chemical properties (acid value, ester value and ester value after acetylation) were also studied. Composition of essential oils were identified, and contained (22.78\%) phyllandrene and (23.85\%) myristicin as the major terpene hydrocarbon compounds found in dill and parsley essential oils, respectively. The ability of extracted essential oils of dill and parsley as antimicrobial activity for (bacteria, yeast and mold) and as natural antioxidant agent applied in sunflower oil were also undertaken. The results indicated that the extracted essential oils of dill and parsley had antimicrobial activity which caused to inhibit the microorganisms growth and also, using these extracted essential oils as antioxidant which caused to improve the sunflower oil stability as natural extracts, achieved nutritional and economical gain.
\end{abstract}

\section{INTRODUCTION}

Some leafy vegetables such as dill (Anethum graveolens) and parsley (Petroselinum sativum) as well as peppermint (Mentha piperita) are considered to be among the most famous, and important popular plants in Egypt and all over the world. These aforementioned crops are commercially cultivated for utilization of their consumed leaves, their characteristic flavor, nutritive value and medical effects. Many investigators reported that dill and parsley are called green drugs. This may be attributed to their medical effects on minimizing and curing stomach and bladder pains, besides headache and toothache (Holden, 1965 and Francis, 1987).

Dill (Anethum graveolens L.), a biennial or annual herb of the parsley family (Apiaceae or Umbelliferae), is native to south-west Asia or southeast Europe and cultivated since ancient times. The leafy tops can be clipped and used in cottage cheese, potato salad, cream cheese, tomato soup and salads (Bailer et al 2001). Also, Mohamed et al (2001), demonstrated that parsley leaves were rich in ascorbic acid content $676.10 \mathrm{mg} / 100 \mathrm{~g}$ (on dry weight basis). Also, they found that parsley leaves contained a high amounts of total chlorophylls and total pheophytin, which were 1654.63 and $9.48 \mathrm{mg} / 100 \mathrm{gm}$ (on dry weight basis).

Faten (1998) reported that, the percentage of essential oil of dill and parsley were 1.2 and $0.8 \%$ (on dry weight basis), respectively. The physical properties (specific gravity at $15^{\circ} \mathrm{C}$, refractive index at $20^{\circ} \mathrm{C}$, optical rotation and solubility in alcohol for dill oil were $0.8950,1.4822,+75^{\circ}$ and soluble in $80 \%$ ethyl alcohol, while parsley oil were 0.8892 , $14842,-3^{\circ}$ and soluble in $75 \%$ ethyl alcohol. Also, the chemical properties (acid number, ester number and ester number after acetylation) of dill and 
parsley oils were, $(0.8,33.6$ and 78.3$)$ and (1.5, 10.2 and 20.8) for dill and parsley oil, respectively.

On the other hand, Aly (1992) analyzed the essential oils of parsley herb and identified the following constituents: myrcene, $\alpha$ - pinene, camphene, $\beta$-pinene, $\mathrm{y}$-terpinene, 1, 3, $8-p-$ menthetriene, $p$ - cymene, 1-methyl - 4 - isopropyl benzene, $p$-dimethyl stiarene, $\beta$-carbophyliene, $\alpha$ hyomioline, $\beta$-cylrene, $\beta$-pharinene, $\alpha$ - pharinene, terpinene - 4 - ol, 2, $8 p$ - menthadaiene -1 - ol, $\alpha$ - terpinol, cis-carviol, cumin aldhyde, carvacol and apiole.

Meanwhile, Megahed (1980) found that, the essential oil of dill contained $\alpha$-pinene, $\beta$-pinene, $\alpha$ phyllandrene, limonene, terpinene, $p$-cymene, methyl chavicol, anithol, myristicin and apiole.

Spices and herbs are used in food mainly for their flavors and aroma, in addition, certain spices prolong the storage life of foods due to their bacteriostatic or bactericidal activity, and for preventing rancidity using to their antioxidant activity (Shelef et al 1980). On the other hand, essential oils for many plants and spices were active against various food-borne bacteria and molds (Gould, 1996).

It is of interest to use the spices and their extracts as antibacterial agents in foods which can be attributed to use in foods because of: (1) their safety, as food additives being a trend toward the use of natural plant substances; (2) the reduction of salt ad sugar in dietary foods which caused to enhance flavor. Most essential oils of spices are classified as GRAS (generally regarded as safe) and considered to contain the antimicrobial activity of spices (Ismaiel \& Pierson, 1990).

Most of the antimicrobial activity in essential oils derived from spices and culinary herbs appears to derive from phenolic compounds, while other constituents are believed to contribute little to the antimicrobial effect (Delaquis et al 2002).

This study was aimed to investigate the chemical composition of fresh dill and parsley herbs as well as studying the physicochemical properties of identified essential oils and its composition. The investigation was also undertaken the utilizing of their essential oils as natural antimicrobial and antioxidant agents.

\section{MATERIALS AND METHODS}

\section{Materials}

Fresh dill (Anethum graveolens) and parsley (Petroselinum sativum) were obtained from Aromatic and Medicinal Plants at El-Khairiya Barrage, Horticulture Research Institute, Agricultural Re- search Center, Giza, Egypt at season (2007). The root portions of the whole herbs were trimmed to obtain the herbs, then washed with current water, sorted and cut into small pieces, packed in polyethylene bags at refrigerator till uses.

Refined Sunflower oil free from antioxidant was purchased from Cairo Oils and Soap Company, ElBadrashin, Giza, Egypt. Butylated hydroxy toluene $(\mathrm{BHT})$ as synthetic antioxidant was obtained from Gerbsaure Chemical Co. Ltd. Germany.

The strains were obtained from Cairo Mircen, Faculty of Agriculture, Ain Shams University, Egypt. The microorganisms tested were: Gram negatives (Pseudomonas flourescens and Escherichia coli; Gram positives (Staphylococcus aureus and Bacillus subtilus); yeast (Saccharomyces cerevisiae); and mold (Aspergillus niger).

\section{Analytical methods}

Moisture content, total solids, ether extract (fixed and essential oils), crude protein, total carbohydrates, crude fibers, ash, chlorophyll a, chlorophyll b, carotenoids, $\beta$-carotene and ascorbic acid were determined according to methods described in the A.O.A.C. (2000).

Minerals content for dill and parsley from ( $\mathrm{Na}$, $\mathrm{Ca}$ and $\mathrm{K}$ ) were determined by using Emission Flame Photometer (Model Corning 410). Mean while, $\mathrm{Zn}, \mathrm{Fe}, \mathrm{Mg}, \mathrm{P}$ and $\mathrm{Cu}$ were determined by using Atomic Absorption Spectrophotometer (Perkin-Elmer Instrument model 2380).

Essential oils from fresh dill and parsley herbs were obtained by steam distillation (Guenther, 1961), by using a Clevenger apparatus for more than 3 hours (Egyptian Pharmacopeia, 1987). The obtained essential oils were filtered and dried by anhydrous sodium sulphate before analysis.

Also, specific gravity at $15^{\circ} \mathrm{C}$, refractive index at $20^{\circ} \mathrm{C}$, optical rotation, solubility in diluted ethyl alcohol, acid value (as oleic acid) and ester value of the essential oils for tested samples were determined according to the methods described by the A.O.A.C.(2000).

The composition of essential oils for dill and parsley were identified with GC-MS analysis by using GC.5890A, Hewlett-Packard, Helium was used as the carrier gas under the following conditions: Oven temp. $80^{\circ} \mathrm{C}$, oven equal time $2.00 \mathrm{~min}$., inj. temp. $150^{\circ} \mathrm{C}$, interface temp. $230^{\circ} \mathrm{C}$, sampling time $3.0 \mathrm{~min}$, column DB-1 $(30.0 \mathrm{~m}$. x $0.250 \mathrm{~mm}$. X 0.25 micron), split less injection, column pressure $50 \mathrm{kpa}$, column flow rate $0.8 \mathrm{ml} / \mathrm{min}$. Oven temp. progs: Initial temp. $80^{\circ} \mathrm{C} / 2 \mathrm{~min}$. rate $5.0^{\circ} \mathrm{C} / \mathrm{min}$, 
$200^{\circ} \mathrm{C} / 10 \mathrm{~min}$. mass range $40-350 \mathrm{M} / 8$, solvent cut $3 \mathrm{~min}, \mathrm{GC}$ prog. time $36 \mathrm{~min}$. detector gain $1.8 \mathrm{kv}$.

Antimicrobial activity was determined using the method described by Sleigh \& Timburg (1981). The inhibition zones of microorganisms growth produced by dill and parsley essential oils were measured in $(\mathrm{mm})$ and tabulated. Also, different concentrations $200,300,400$ and 500 ppm of essential oils under the investigation were carried out, the filter discs were conducted to the abovementioned concentrations and the used Petri dishes contained water agar media. The lowest quantity of the essential oils required to inhibit the growth of the microorganisms was designated as the minimum inhibitory concentration (MIC).

The oxidative stability of volatile oils were determined by Rancimat 679 (Metrom Ltd., CH 9100 Herisau, Switzerland) according to the method described by the A.O.C.S. (1993).

\section{RESULTS AND DISCUSSION}

\section{Chemical composition of fresh dill and parsley herbs}

The chemical analysis of fresh dill and parsley herbs are shown in Table (1). The results indicated that the moisture content of dill is higher than that of parsley, they were $89.76 \%$ and $83.22 \%$, respectively.

The high percentage of ether extract related to the lower percentage of moisture in herb which may give an advantage to the plant as a good source of oil. While, a reverse trend was found for dry matter content, since parsley had a higher dry matter than that of dill. Parsley had a higher content of ether extract, total carbohydrates and ascorbic acid, when compared to dill herb. These values for dill herb were 4.49, 27.25, 38.87, 13.38 and $16.02 \%$ (on dry weight basis) for ether extract, crude protein, total carbohydrates, crude fiber and ash. While, the corresponding values for parsley herb were 5.95, 21.72, 46.97, 11.10 and $14.26 \%$ (on dry weight basis), respectively. However, parsley had higher contents of ascorbic acid either in fresh weight basis or dry weight basis.

The amount of different pigments in two herbs were $174.32,385.35$, and $145.12 \mathrm{mg} / 100 \mathrm{~g}$ (on dry weight basis) for carotenoids, chlorophyll (a) and chlorophyll (b) for dill. While, the corresponding values were $83.01,229.07$ and $78.46 \mathrm{mg} / 100 \mathrm{gm}$ (on dry weight basis) for parsley.

Table 1. Chemical composition of fresh dill (Anethum graveolens) and parsley (Petroselinum sativum) herbs*

\begin{tabular}{|l|c|c|c|c|}
\hline \multirow{2}{*}{ Constituents } & \multicolumn{2}{c|}{ Dill } & \multicolumn{2}{c|}{ Parsley } \\
\cline { 2 - 5 } & FWB $^{* *}$ & DWB $^{* *}$ & FWB & DWB \\
\hline Moisture content (\%) & 89.76 & - & 83.52 & - \\
Total solids (\%) & 10.24 & 100 & 16.48 & 100 \\
Ether extract (fixed and essential oils) \% & 0.46 & 4.49 & 0.98 & 5.95 \\
Crude protein (\%) & 2.79 & 27.25 & 3.58 & 21.72 \\
Total carbohydrates (\%) & 3.98 & 38.87 & 7.74 & 46.97 \\
Crude fiber (\%) & 1.37 & 13.38 & 1.83 & 11.10 \\
Ash (\%) & 1.64 & 16.02 & 2.35 & 14.26 \\
Ascorbic acid (mg/100g) & 56.73 & 554.00 & 112.82 & 682.77 \\
Carotenoids (mg/100g) & 17.85 & 174.32 & 13.68 & 83.01 \\
Chlorophyll (A) (mg/100g) & 39.46 & 385.35 & 37.75 & 229.07 \\
Chlorophyll (B) (mg/100g) & 14.86 & 145.12 & 12.93 & 78.46 \\
Total chlorophyll (mg/100g) & 54.32 & 530.47 & 50.68 & 307.53 \\
B-carotene (mg/100g) & 3.47 & 33.89 & 5.76 & 34.95 \\
Essential oil (\% v/w) & 0.09 & 0.879 & 0.07 & 0.425 \\
\hline
\end{tabular}

${ }^{*}$ Fresh herb $=$ whole herb (leaves + stem).

${ }^{\star *}$ FWB $=$ Fresh weight basis. $\quad{ }^{* \star *}$ DWB $=$ Dry weight basis. 
Results also indicated that, $\beta$-carotene content was 33.89 and $34.95 \mathrm{mg} / 100 \mathrm{gm}$ (on dry weight basis) for dill and parsley, respectively.

Consequently essential oils for both dill and parsley have an important constituent since it could be used as a flavor component in food industry. The results showed that the dill and parsley contained 0.879 and $0.425 \%(\mathrm{v} / \mathrm{w})$ ) of essential oils (on dry weight basis), respectively.

These results are in agreement with those reported by El-Nikeety et al (2000) and Mohamed et al (2001), they reported that the parsley herb contained $23.53 \%$ crude protein, $1.69 \%$ ether extract, $14.23 \%$ fibers and $13.98 \%$ ash (on dry weight basis).

\section{Minerals content of fresh dill and parsley herbs}

The contents of different minerals in two herbs (dill and parsley) are presented in Table (2). These results indicated that the contents of: $\mathrm{Ca}, \mathrm{Na}, \mathrm{Zn}$ and $\mathrm{Cu}$ were higher in dill herb than that of parsley herb, which were 1394.34, 222.17, 53.03 and $26.46 \mathrm{mg} / 100 \mathrm{~g}$ (on dry weight basis), respectively for dill herb, while, the corresponding values were 1302.67, 207.22, 5.16 and $4.19 \mathrm{mg} / 100 \mathrm{gm}$ (on dry weight basis), respectively for parsley. On contrary, parsley contained higher contents of $\mathrm{P}, \mathrm{K}$ and $\mathrm{Mg}$ than that of dill herb.

Also, from (Table 2) it could be showed that, calcium, phosphorus and potassium were the predominant minerals in both dill and parsley herbs. These results are similar with that obtained by Slupski et al (2005).

Conclusively, dill and parsley are an excellent source of mineral constituents whose importance in the human diet is undisputable. Some of them, such as potassium, sodium, phosphorus, calcium, magnesium, or iron, are indispensable in the sustainment of human health.

\section{Physicochemical characteristics of essential oils for dill and parsley}

Some physicochemical characteristics of dill and parsley essential oils were determined, and the obtained results are presented in Table (3).

These results indicated that the specific gravity at $15^{\circ} \mathrm{C}$, refractive index at $20^{\circ} \mathrm{C}$ and acid value (as oleic acid) for essential oils of parsley were higher than that of essential oils for dill , which recorded $0.8974,1.4892$ and 1.02 , respectively for essential oils of dill. The corresponding values for essential oils of parsley were $0.9463,1.5124$ and 1.45 , respectively.
Whereas, optical rotation an important criteria for judging the purity of the essential oils, Guenther (1961). Which was $+65^{\circ}$ and $-4^{\circ}$ for essential oils of dill and parsley, respectively.

On the other hand, essential oils of dill had a higher value of both ester value and ester value after acetylation. Which, were (35.47 and 82.37) for dill compared with that (9.73 and 21.62) for parsley essential oils. Generally the physical and chemical properties values agreed with those mentioned by Megahed (1980) and Faten (1998).

\section{Composition of essential oils for dill and pars- ley}

Essential oils have an important values since it could be used as a flavor components. Using Gas Chromatography and identification by Mass Spectrometry were used to determine the chemical components of fresh dill and parsley essential oils. The results of chemical composition of these essential oils are shown in Table (4) and Figures (1 and 2).

These results represented that parsley oil had the highest concentration of $\beta$-pinene (19.47\%) and myristicin (23.85\%). Both considered the major components in fresh parsley essential oils. These results are in agreement with those reported by Ashraf et al (1979).

Whereas, the predominant major identified components in the fresh dill essential oils were phyllandrene $(22.78 \%)$ and Limonene $(20.52 \%)$, also, it contains apiole (12.73\%) and carvone (13.22\%). These results are in agreement with those obtained by Faten (1998).

\section{Antimicrobial activity of essential oils for dill and parsley}

Effect of extracted volatile oils for dill and parsley were tested on different microorganisms (gram negative and positive bacteria), yeast and mold. The inhibition zones $(\mathrm{mm})$ and minimum inhibitory concentration (ppm) of different microorganisms by using dill and parsley essential oils were illustrated in Table (5). The most striking feature of the chosen microorganism have been either pathogenic or food spoilage microorganisms.

The results in Table (5) indicated that the gram positive bacteria (Staphylococcus aureus and $\mathrm{Ba}$ cillus subtilus) were more sensitive to the effect of essential oils than gram-negative ones (Pseudomonas flourecens and E. coli). Also, it could be noticed that yeast (Saccharmoyces cerevisae) was more sensitive than mold (Aspergillus niger) by adding 200, 300,400 and 500 ppm for essential 
Table 2. Mineral contents of fresh dill and parsley herbs* $(\mathrm{mg} / 100 \mathrm{~g})$

\begin{tabular}{|l|c|c|c|c|}
\hline \multirow{2}{*}{\multicolumn{1}{|c|}{ Mineral }} & \multicolumn{2}{c|}{ Dill } & \multicolumn{2}{c|}{ Parsley } \\
\cline { 2 - 5 } & FWB $^{* *}$ & DWB $^{* * *}$ & FWB & DWB \\
\hline Sodium (Na) & 22.75 & 222.17 & 34.15 & 207.22 \\
Calcium (Ca) & 142.78 & 1394.34 & 214.68 & 1302.67 \\
Magnesium (Mg) & 23.65 & 230.96 & 49.63 & 301.15 \\
Phosphorus (P) & 43.63 & 426.07 & 83.52 & 506.80 \\
Iron (Fe) & 4.21 & 41.11 & 6.78 & 41.14 \\
Potassium (K) & 547.82 & 5349.8 & 978.74 & 5938.96 \\
Copper (Cu) & 2.71 & 26.46 & 0.69 & 4.19 \\
Zinc (Zn) & 5.43 & 53.03 & 0.85 & 5.16 \\
\hline
\end{tabular}

${ }^{*}$ Fresh herb $=$ whole herb (leaves + stem).

** FWB = Fresh weight basis.

*** DWB $=$ Dry weight basis.

Table 3. The physicochemical properties of essential oils for dill and parsley

\begin{tabular}{|l|c|c|}
\hline \multicolumn{1}{|c|}{ Parameter } & Essential oils of dill & Essential oils of parsley \\
\hline Color & Greenish & Yellowish \\
Volatile oil content $\%(\mathrm{v} / \mathrm{w})$ & 0.879 & 0.425 \\
Specific gravity at $15^{\circ} \mathrm{C}$ & 0.8974 & 0.9463 \\
Refractive index at $20^{\circ} \mathrm{C}$ & 1.4892 & 1.5124 \\
Optical rotation & $+65^{\circ}$ & $-4^{\circ}$ \\
Solubility & Soluble in $85 \%$ ethanol & Soluble in $90 \%$ ethanol \\
Acid value(\% as oleic acid) & 1.02 & 1.45 \\
Ester value & 35.47 & 9.73 \\
Ester value after acetylation & 82.37 & 21.62 \\
\hline
\end{tabular}

oils of dill and parsley. These results were found to be in agreement with the results obtained by ElBaroty (1988).

Also, it could be noticed that, there is a relationship between the inhibitory act and chemical structures of the most abundant compounds in the essential oils under this investigation. However, both dill and parsley essential oils are characterized by containing a great amount of hydrocarbons and ketons such as (limonene 20.52\%; phyllandrene $22.78 \%$ and carvone $13.22 \%$ ) for dill essential oils and ( $\beta$-pinene $19.47 \%$ and Myristicin $23.85 \%$ ) for parsley essential oil (Table 5).
The dill essential oil had the highest effect as antimicrobial against the microorganisms than parsley essential oil, these observations due to dill essential oil might be the presence of phenolic ether dill apiole $(12.73 \%)$. These results are in agreement with data reported by El-Baroty (1988), who indicated that there is a relationship between the chemical composition of the oil and its antimicrobial effect.

Generally, from the previous data, It could be concluded that the dill and parsley essential oils may act as an antimicrobial activity against investigated microorganisms. 
Table 4. Main components of essential oils for dill and parsley

\begin{tabular}{|c|l|c|c|}
\hline \multirow{2}{*}{$\begin{array}{c}\text { Peak } \\
\text { No. }\end{array}$} & \multirow{2}{*}{ Components } & \multicolumn{2}{|c|}{ Aromatic herbs } \\
\cline { 3 - 4 } & & $\begin{array}{c}\text { Dill essential oil } \\
(\%)\end{array}$ & $\begin{array}{c}\text { Parsley essential oil } \\
(\%)\end{array}$ \\
\hline 1 & a-pinene & 6.54 & 0.85 \\
2 & $\beta$ - pinene & 4.98 & 19.47 \\
3 & Camphene & - & 4.20 \\
4 & limonene & 20.52 & Trace \\
5 & P-Cymene & Trace & 11.59 \\
6 & Myristicin & 7.20 & 23.85 \\
7 & Phyllandrene & 22.78 & 5.13 \\
8 & 3-Carene & - & 7.34 \\
9 & Terpinolene & Trace & 0.37 \\
10 & Citronellol & - & 0.93 \\
11 & Eugenol & 0.78 & - \\
12 & Linalool & 0.26 & 0.09 \\
13 & Linalyl acetate & 5.14 & 0.12 \\
14 & Apiole & 12.73 & 10.96 \\
15 & Carvone & 13.22 & - \\
16 & Caryophyllene & 0.15 & - \\
\hline
\end{tabular}

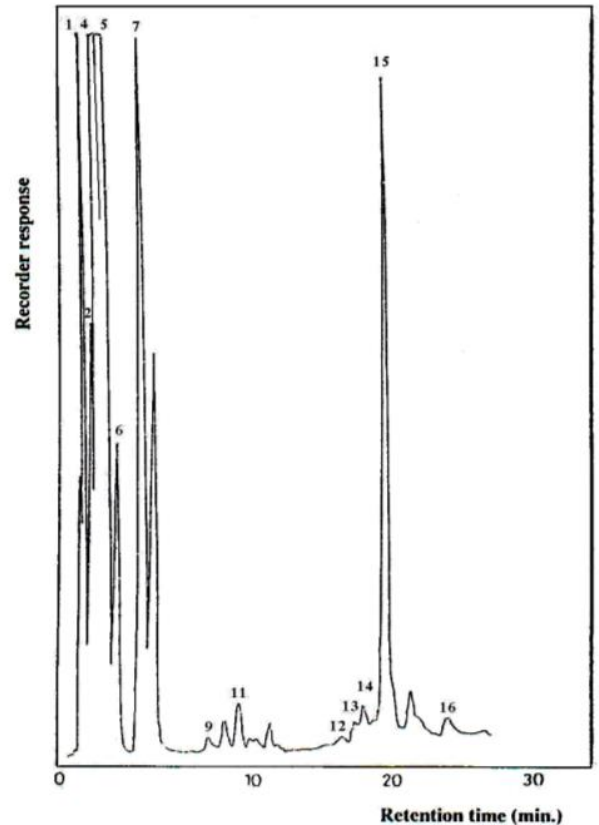

Figure 1. Gas chromatogram of the volatiles in dill

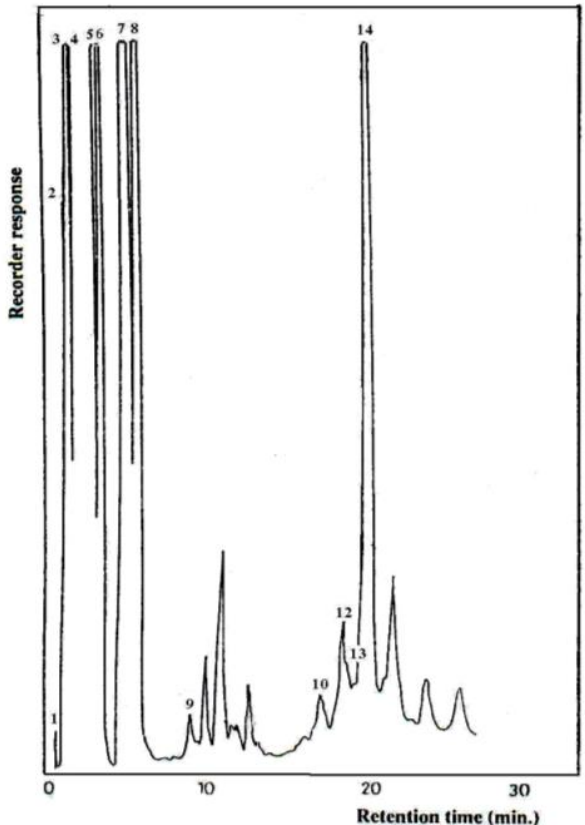

Figure 2. Gas chromatogram of the volatiles in parsley 
Table 5. Effect of using dill and parsley essential oils for Inhibition zones $(\mathrm{mm})$ and minimum inhibitory concentration $(\mathrm{ppm})$ on different microorganisms

\begin{tabular}{|l|c|c|c|c|}
\hline \multirow{2}{*}{ Microorganism } & \multicolumn{2}{|c|}{ Dill essential oil } & \multicolumn{2}{c|}{ Parsley essential oil } \\
\cline { 2 - 5 } & Zone $^{*}$ & MIC $^{* *}$ & Zone & MIC \\
\hline Staphylococcus aureus & 30 & 300 & 17 & 300 \\
Bacillus subtilus & 32 & 300 & 16 & 300 \\
Pseudomonas flourescens & 14 & 400 & 12 & 400 \\
Escherichia coli & 18 & 400 & 14 & 300 \\
Saccharomyces cerevisiae & 20 & 300 & 15 & 400 \\
Aspergillus niger & 17 & 400 & 11 & 400 \\
\hline
\end{tabular}

* The zone of inhibition ( $\mathrm{mm})$.

${ }^{* *} \mathrm{MIC}=$ Minimum inhibitory concentration (ppm).

\section{Antioxidant activity}

The essential oils extracted from dill and parsley herbs were added to sunflower oil with the concentrations of 200, 400, 800, 1200 and $1400 \mathrm{ppm}$. Stability of sunflower oil was measured by Rancimate method.

From results in Table (6), it is clear that the addition of essential oils extracted from dill and parsley caused to increase the stability of sunflower oil at all used concentrations up to induction 8 hours in sunflower oil without addition of essential oils compared with that induction for 10 hours in sunflower oil with $200 \mathrm{ppm}$ butylated hydroxy toluene (BHT) to 11.30, 10.30; 13.50, 12.00; 19.30, 16.50; 23.50, 19.30 and 24.30 and 20.50 hours for sunflower oil with 200, 400, 800, 1200 and 1400 ppm essential oil from dill and parsley herbs, respectively (Table 6).

Also, the addition of dill and parsley essential oils may act as antioxidant and caused to increase the shelf life of sunflower oil during storage at ambient temperature. Therefore, it could be used dill and parsley essential oils instead of using synthetic antioxidants.
Table 6. Effect of adding different concentrations of dill and parsley essential oils on the oxidative stability of sunflower oil

\begin{tabular}{|l|c|}
\hline \multicolumn{1}{|c|}{ Items } & $\begin{array}{c}\text { Oxidative } \\
\text { stability } \\
\text { (Induction } \\
\text { periods } \\
\text { hours) }\end{array}$ \\
\hline Sunflower oil ( Control) & 8 \\
Sunflower oil + 200 ppm (BHT) & 10 \\
Dill essential oil added in ppm & \\
Sunflower oil + 200 ppm & 11.30 \\
Sunflower oil + 400 ppm & 13.50 \\
Sunflower oil + 800 ppm & 19.30 \\
Sunflower oil +1200 ppm & 23.50 \\
Sunflower oil +1400 ppm & 24.30 \\
Parsley essential oil added in ppm & \\
Sunflower oil + 200 ppm & 10.30 \\
Sunflower oil + 400 ppm & 12.00 \\
Sunflower oil + 800 ppm & 16.50 \\
Sunflower oil +1200 ppm & 19.30 \\
Sunflower oil +1400 ppm & 20.50 \\
\hline
\end{tabular}




\section{REFERENCES}

Aly, S.E. (1992). Technological and Microbiological Studies on the Essential Oils of Some Umbelliferae Plants. pp. 61-68. Ph.D. Thesis, Fac. of Agric., Cairo Univ., Egypt.

A.O.A.C. (2000). Official Methods of Analysis. Association of Official Analytical Chemists, $17^{\text {th }} \mathrm{Ed}$, edited by W. Horwitz, A.O.A.C., Washington, D.C., USA.

A.O.C.S. (1993). Official and Tentative Methods. American Oil Chemists Society, $6^{\text {th }}$ Ed., Puplished by the American Oil Chemists Society, Champaign, U.S.A.

Ashraf, M.; P.J. Sandra; T. Saed and M.K. Bhatty (1979). Studies on the essential oils of $\mathrm{Pa}$ kistani spices of family Umbelliferae xxx 111- Petrosilinum Crispum Miller (Parsley) seed oil. Pakistan Journal Scientific and Industrial Research, 2(5): 262-264.

Bailer, J.; T. Aichinger; G. Hackl; K. Hueber and M. Dachler (2001). Essential oil content and composition in commercially available dill cultivars in comparison to caraway. Industrial Crops and Products, 14(3): 229-239.

Delaquis, P.J.; K. Stanich; B. Girard and G. Mazza (2002). Antimicrobial activity of individual and mixed fractions of dill, cilantro, coriander and eucalyptus essential oils. International J. of Food Microbiology, 74(1-2): 101-109.

Egyptian Pharmacopeia (1987). General Organization for Governmental Printings, Cairo, Egypt.

El-Baroty, G.S. (1988). Biochemical Studies on Some Naturally Occurring Substances and Their Relation to Lipid Oxidation. pp. 73-77. Ph.D. Thesis, Fac. of Agric., Cairo Univ., Egypt.

El-Nikeety, M.M.; A.T. El-Akel; M.M. Abd ElHady and A.Z. Badi (2000). Changes in physical properties and chemical constituents of parsley herb volatile oil during storage. Egypt. J. Food Sci., 28(49): 35-49.

Faten, R.M. (1998). Biochemical Studies on Some Medicinal and Aromatic Plants. pp. 57-60. Ph. D. Thesis, Fac. of Agric., Zagazig Univ., Egypt. Francis, F.J. (1987). Handbook of Food Colorants, (Patents). Food, Nutrition Press, Westport, Conn.

Gould, G.W. (1996). Industry perspective on the use of natural antimicrobial and inhibitors for food applications. J. Food Prot. (Suppl.): 82-86.

Guenther, E.S. (1961). The Essential Oils, $3^{\text {rd }}$ Ed, I, II, III, pp. 30-33. Published by D.Van Nostrand Company, Inc., New York.

Holden, M. (1965). Chemistry and Biochemistry of Plant Pigments., pp. 124-135. Goodwin, T.W., (Editor), Academic Press. New York.

Ismaiel, A. and M.D. Pierson (1990). Inhibition of growth and germination of $C$. botulinum $33 A, 40 B$, and $1623 E$ by essential oil of spices. J. Food Sci., 55(6): 1676-1678.

Megahed, M.Y. (1980). Studies on Production, Characteristics and Utilization of Dill Essential Oils. pp. 44-47. M.Sc. Thesis, Fac. of Agric., Cairo Univ., Egypt.

Mohamed, E.A.; S.H. Hamed and I.M. Hemmat (2001). Influence of pre-treatments and dehydration process on chlorophylls retention of parsley, coriander and peppermint leaves. Egyptian $\mathbf{J}$. Agric. Res. 79(3): 1111-1125.

Shelef, L.A.; O.A. Naglik and D.W. Bogen (1980). Sensitivity of common food-borne bacteria to the spices sage, rosemary, and allspice. J. Food Sci., 45:1042-1044.

Sleigh, J.D. and M.C. Timburg (1981). Notes of medical bacteriology, p. 43. Churchill Livingstone, London.

Slupski, J.; Z. Lisiwska and W. Kmieik (2005). Contents of macro and micro-elements in fresh and frozen dill (Anethum graveolens L.). Food Chemistry, 91: 737-743. 